\title{
The Influence of Online Learning on the Development of Students at SD Muhammadiyah 5 Porong During the Covid Pandemic [Pengaruh Pembelajaran Online Terhadap Perkembangan Siswa SD Muhammadiyah 5 Porong di Tengah Pandemi Covid 19]
}

\author{
May Lucyana Kartono Putri * \\ \{maylucyana19@gmail.com \} \\ Fakultas Psikologi dan Ilmu Pendidikan, Universitas Muhammadiyah Sidoarjo, Indonesia
}

\begin{abstract}
The COVID-19 pandemic has disrupted the online learning process. So a solution is needed to answer these problems. Online learning can solve this problem. The purpose of this study was to obtain an overview of online implementation at Muhammadiyah 5 Porong Elementary School. The research method used the interview method by asking questions to 1 respondent. Based on the data it was found that all students did online learning and it was carried out according to their respective lesson schedules. The material information obtained through online learning is not effective for elementary school age children. The media used during online learning and the majority use the Google Classroom and Google Meet systems. Although this system can be used as a solution for conditions during the COVID-19 pandemic, several obstacles such as unstable internet networks, limited quotas, and others. In conditions of an outbreak Covid-19, online learning can be used with consideration of students' conditions, so they will get used to adjusting to the online system, learning can be done well. In addition, this online system can be used additional experiences for students in the future. The positive influence can be done anywhere and anytime according to the existing conditions. Because more time is spent at home, online learning can also increase the closeness between students and their parents. The negative influence of students who complain about the ineffectiveness of online learning, such as too many assignments, different internet networks for each student, difficulty understanding the material provided by the teacher, students also get bored quickly, and many others.
\end{abstract}

Keywords: Online, Students, Learning, Technology

Abstrak. Pandemi covid 19 telah mengganggu proses pembelajaran online. Maka
diperlukan solusi untuk menjawab permasalahan tersebut. Pembelajaran secara daring lah
yang bisa mengatasi masalah tersebut. Tujuan penelitian ini adalah untuk memperoleh
gambaran pelaksanaan daring pada saat di Sekolah Dasar Muhammadiyah 5 Porong.
Metode Penelitian menggunakan metode wawancara dengan mengajukan pertanyaan
terhadap 1 orang responden. Berdasarkan data ditemukan bahwa semua siswa melakukan
pembelajaran daring dan dilaksanakan sesuai jadwal pelajaran masing-masing. Informasi
materi yang diperoleh melalui pembelajaran daring tersebut tidak efektif bagi anak usia
SD. Media yang digunakan selama pembelajaran daring dan mayoritas menggunakan
sistem Google Classroom dan Google meet. Walaupun sistem ini bisa dijadikan solusi bagi
kondisi saat pandemi covid 19 ini, beberapa hambatan seperti jaringan internet tidak stabil,
kuota terbatas, dan lainnya. Dalam kondisi adanya wabah Covid-19, pembelajaran daring 
dapat digunakan dengan pertimbangan memperhatikan kondisi siswa, sehingga akan terbiasa menyesuaikan dengan sistem daring, pembelajaran dapat terlaksana dengan baik. Selain itu, sistem daring ini dapat dijadikan pengalaman tambahan bagi siswa dimasa yang akan datang. Pengaruh positifnya bisa dilakukan dimana saja dan kapan saja sesuai dengan kondisi yang ada. Karena waktu yang dihabiskan dirumah jauh lebih banyak, pembelajaran daring juga dapat menambah kedekatan antara siswa dengan orang tuanya. Pengaruh negatifnya siswa yang mengeluh akan kurang efektifnya pembelajaran daring ini, seperti tugas yang diberikan terlalu banyak, jaringan internet yang berbeda-beda pada tiap siswa, sulitnya memahami materi yang diberikan oleh guru, siswa juga menjadi cepat bosan, serta masih banyak yang lainnya.

Kata Kunci: Daring, Siswa, Pembelajaran, Tekhnologi

\section{Pendahuluan}

Pandemi Covid-19 merupakan krisis kesehatan yang terjadi di dunia saat ini. Virus ini sangat cepat menyebar dan meluas sampai di seluruh dunia yang mengakibatkan kerugian besar di berbagai sektor. Menurut Khasanah et al., salah satu sektor yang mengalami dampak dari pendemi ini adalah pendidikan. Banyak negara memutuskan untuk menutup sekolah, perguruan tinggi dan universitas sebagai upaya untuk memutus rantai penyebaran Covid-19. Proses belajar mengajar dilakukan secara daring dan menghindari kegiatan tatap muka. Pembelajaran daring sangat bermanfaat di masa pendemi saat ini, agar siswa tetap mengikuti pembelajaran walaupun sedang dirumah saja. Akan tetapi , pembelajaran daring juga memiliki banyak kendala khususnya untuk siswa sekolah dasar. [1]

Banyak siswa di tingkat sekolah dasar mengalami kesulitan dalam pembelajaran daring seperti terkendala jaringan, kuota terbatas, dll. Pembelajaran daring ditingkat sekolah dasar biasanya hanya diberikan tugas oleh guru tanpa disertai penjelasan mengenai materinya terlebih dahulu. Sehingga proses belajar siswa hanya bergantung pada orang tua. Akan tetapi, orangtua terkadang tidak bisa sepenuhnya membantu karena terkendala waktu, pengetahuan, dan keahlian dalam teknologi Pentingnya pembelajaran daring yaitu penguasaan tekhnologi karena jika tidak bisa menguasai tekhnologi maka tidak akan bisa menggunakan aplikasi yang ada dismarthphone.[2] Berdasarkan topik penelitian yang dilakukan di Sekolah Dasar Muhammadiyah 5 Porong pembelajaran online ini tidak efektif bagi anak usia SD. Menurut wawancara dari guru SD Muhammadiyah 5 Porong pengalaman daring di masa pandemi banyak kendalanya. Awalnya lancar, hampir semua siswa bisa mengikuti tapi akhir-akhir semakin sedikit siswa yang ikut daring,karena banyak faktor kendala jaringan,kuota, dll. Tujuan adanya penelitian ini untuk mengetahui perkembangan siswa SD Muhammadiyah 5 Porong pada saat pandemi covid 19 ini. Pada pandemi covid-19 ini telah memberikan kita begitu banyak pelajaran, tidak hanya tentang upaya memutuskan rantai penularannya, tapi juga bagaimana anak-anak sekolah tetap belajar dan bagaimana sekolah-sekolah bereaksi memanfaatkan teknologi dalam proses belajar mengajar.[3]

\section{Metode Penelitia}

Penelitian ini menggunakan metode penelitian kualitatif deskriptif. Pendekatan kualitatif merupakan proses penelitian untuk memahami masalah-masalah sosial atau manusia dengan menganalisis kata-kata untuk menciptakan gambaran kompleks dan menyeluruh, serta melaporkan pandangan informasi terperinci yang diperoleh dari para sumber informasi dalam 
lingkungan alami. Pendekatan kualitatif juga bertujuan untuk menyelidiki, menemukan, menggambarkan, serta menjelaskan kualitas atau keistimewaan dari pengaruh sosial yang tidak dapat dijelaskan, diukur, atau digambarkan melalui pendekatan kuantitatif.[4] Teknik pengambilan data dalam penelitian ini melalui wawancara, dokumentasi dan observasi, adapun trianggulasi yang di pakai dalam penelitian ini adalah trianggulasi teknik. Penggunaan metode kualitatif ini dimaksudkan untuk memperoleh gambaran mengenai Pengaruh pembelajaran online terhadap perkembangan siswa SD Muhammadiyah 5 Porong.

\section{Hasil dan Pembahasan}

Pengertian Internet Seperti yang kita ketahui bersama bahwa internet telah mencakup seluruh aspek dalam kehidupan manusia termasuk dalam bidang pendidikan. Seiring dengan perkembangan zaman kini internet digunakan sebagi media pembelajaran. Oleh karena itu perlu kita ketahui apa itu internet dan bagaimana peran dalam dunia pembelajaran. Internet adalah kumpulan atau jaringan dari computer yang berada pada seluruh dunia. Internet merupakan kependekan dari interconnection-networking secara harfiah ialah system global dari seluruh jaringan computer yang terhubung satu sama lain dengan menggunakan standar Internet Protocol Suite (TCP/IP) untuk melayani seluruh pengguna didunia yang berjumlah hingga miliaran pengguna. Internet menyediakan akses untuk layanan telekomunikasi dan sumber daya komunikasi untuk jutaan pemakainya yang tersebar diseluruh penjuru dunia. Dari pemikiran tokoh-tokoh diatas dapat disimpulakan bahwa internet merupakan jaringan komunikasi yang memiliki fungsi member informasi-informasi sesuai yang dibutuhkan oleh pengakses . Selain itu internet dapat dijadikan sebagai media partner dalam hidup manusia baik untuk keperluan pekerjaan, hiburan, dan bahkan pendidikan.[5] Seperti halnya dengan dunia nyata dunia internet juga memiliki alamat untuk mencari keberadaan informasi-informasi yang diinginkan. Alamat dalam intenet dikenal dengan istilah domain name atau nama domain19. Nama domain ini bersifat otentik jadi tidak ada satu namapun yang sama diseluruh dunia. Informasi-informasi yang terdapat diwebsite dikemas dalam bentuk halaman-halaman yang disebut web page,Sedangkan kumpulan dari halaman web milik suatu pihak yang disatukan disebut website. Pembelajaran daring telah menciptakan hal yang luar biasa, dimana sebelumnya hanya mengandalkan tatap muka dan sekarang mulai beralih ke pembelajaran berbasis komputer. Istilah model pembelajaran daring yaitu memanfaatkan akses internet dengan berbagai aplikasi untuk mendukung pembelajaran dalam hal pembelajaran yang awalnya konvensional menjadi daring.[6]

Bedasarkan hasil wawancara yang dilakukan dengan guru SD Muhammadiyah 5 Porong mengenai pengaruh pembelajaran online terhadap perkembangan belajar siswa adalah sebagai berikut: Pembelajaran online juga diterapkan di SD Muhammadiyah 5 Porong pada masa pandemi covid-19 ini, pembelajaran dilakukan secara jarak jauh (daring) yang sudah dilaksanakan dari pertengahan bulan maret 2019 lalu. Pembelajaran online ini dilaksanakan sesuai kebijakan yang telah ditentukan oleh pemerintah untuk memutus mata rantai penyebaran virus covid-19 ini. Guru sangat keberatan dengan adanya pembelajaran online ini khususnya pada pembelajaran pada Kelas Rendah, mungkin untuk kelas tinggi tidak terlalu berat tetapi untuk kelas rendah pembelajaran online ini sanngat berpengaruh terhadap perkembangan belajar anak. Dimana anak masih membutuhkan bimbingan yang sangat ekstra dalam pembelajaran. Siswa kelas rendah belum mengerti apa-apa sehingga guru kesulitan dalam menyampaikan materi terhadap anak supaya anak dapat memahami materi yang telah disampaikan. Penyampaian materi yang dilakukan oleh guru di SD Muhammadiyah 5 Porong biasanya melalui WA Grup atau google meet, beliau menyampaikan materi berupa Foto/gambar, Audio, 
dan Video tetapi hal ini tidak dapat meyakinkan guru bahwa dengan penyampaian ini anak anak melihat/ mendengarkan materi yang disampaikan.[7]

Namun ada sisi positif nya menggunakan smartphone siswa SD dapat mengerjakan tugas sekolah dari guru dengan mudah, dengan cepat dan banyak dan terjadwal, karena hakekat tugas diberikan sebagai bagian dari proses pembelajaran, maka tugas belajar dikerjakan siswa sesuai dengan pokok bahasan materi pelajaran. Penerapan media pembelajaran online berbantuan google classroom membantu peserta didik dalam kesulitan belajar dan membuat siswa lebih mudah memahami materi pelajaran karena siswa bisa mengakses kembali materi yang dibagikan di google classroom kapan saja.Terkadang ada juga sisi negatif nya yaitu banyak siswa yang mengeluhkan tidak paham terhadap materi yang diajarkan oleh guru karena mereka tidak mendapatkan penjelasan secara langsung.Pembelajaran menjadi kurang efektif. Materi yang didapatkan anak sangatlah minim dan jauh dari acuan minimal yang seharusnya dicapai ketika pembelajaran berlangsung secara normal. Pembelajaran secara daring tidak jauh berbeda dengan pembelajaran secara luring, pemberian tugas tetap ada namun berbeda pada saat di kelas, yang beban tugasnya dikurangi sedikit.Siswa tetap mengerjakan tugas yang diberikan oleh gurunya untuk pengambilan nilai. Pemberian tugas tidak mesti setiap hari, dilihat juga dari situasi dan kondisi pada saat itu apakah memungkinkan untuk diberikan tugas yang sesuai dengan materi atau tidak memungkinkan diberikan tugas.

Dari media pembelajaran yang banyak digunakan pada pembelajaran jarak jauh atau online learning saat ini seperti ELearning, Zoom, Google Meet, dan Google Classroom sebagai alternatif yang tepat bagi guru dan siswa dalam rangka agar bisa melaksanakan proses belajar mengajar yang lebih luas dikala pandemi seperti saat ini.[1] Media diatas merupakan salah satu faktor eksternal yang memberikan pengaruh besar terhadap ketercapaian pembelajaran, dan secara umum media pembelajaran ini memperlancar interaksi antara pendidik dan peserta didik, pendidik dengan sesama pendidik maupun peserta didik dengan teman lainnya yang dapat berkomunikasi dan berinteraksi secara aktif dan komunikatif.[8]

Beberapa penelitian telah membuktikan bahwa banyak pelajar yang menggunakan laptop dan smartphone dalam pembelajaran. Kemampuan laptop dan telepon pintar untuk mengakses internet memungkinkan pelajar untuk mengikuti kegiatan belajar mengajar yang dilaksanakan dalam bentuk konferensi video maupun yang dilaksanakan dalam kelas-kelas online menggunakan layanan aplikasiaplikasi pembelajaran yang tersedia secara online. Namun pembelajaran daring juga memiliki tantangan tersendiri. Salah satunya adalah ketersediaan jaringan internet. Beberapa mengaku kesulitan untuk mengikuti pembelajaran online karena tidak semua wilayah mendapatkan jaringan internet dengan akses lancar. Hal tersebut membuat mereka kesulitan ketika akan mengumpulkan tugas. Selain tantangan mengenai layanan internet, tantangan lainnya adalah kendala biaya. Untuk mengikuti pembelajaran online, para siswa harus mengeluarkan biaya lebih untuk membeli kuota internet. Selain itu, dampak yang dirasakan oleh guru di SD Muhammadiyah 5 Porong yaitu adanya keterbatasan fisik yang sulit mengkomunikasikan materi pada siswa. Karena kondisi psikologis dan kognitif siswa yang berbeda-beda. Hal ini meskipun sudah dengan penggunaan via zoom agar guru dan murid dapat berinteraksi secara tatap muka. [8]

Meskipun itu siswa SD Muhammadiyah 5 Porong tidak patah semangat karena Pembelajaran Daring bukan satu-satunya faktor penurunan motivasi belajar siswa. Faktor eksternal lainnya yang dapat mempengaruhi motivasi belajar siswa seperti kualitas pengajaran, lingkungan belajar, sarana pengajaran, sinyal, dan alat pendukung pembelajaran Daring. Namun sering kali kurangnya antusias siswa didalam mengikuti proses pembelajaran Daring dalam segi tanya jawab, keaktifan belajar siswa didalam kelas Online saat guru memberikan kesempatan bertanya tidak semua siswa memberikan pertanyaan terkadang hanya sebagian kecil yang 
mengajukan pertanyaan sedangkan apabila guru yang memberikan pertanyaan siswa tidak bisa memberikan jawaban. Maka dari itu keaktifan belajar didalam kelas akan berpengaruh terhadap prestasi belajar siswa. Seperti yang telah kita ketahui bahwa kurikulum 2013 mengedepankan karakter anak SD dan guru dapat menerapkannya saat pembelajaran daring. Guru bekerjasama dengan orang tua/wali murid untuk mengawasi kegiatan anaknya. Contoh yang saya ambil adalah siswa kelas rendah, ketika dirumah, siswa tidak serta merta dibebankan oleh guru dengan serangkaian tugas yang banyak, apalagi proses pembelajaran daring dengan tatap muka (video call) via zoom, dll. Mengingat, siswa SD apalagi kelas rendah belum cukup usia untuk menggunakan smartphone. Jadi, siswa diminta untuk membiasakan hidup mandiri. Kegiatannya meliputi merapikan tempat tidurnya, menyapu halaman rumah, mencuci pakainnya sendiri, menjemur pakaiannya sendiri, mencuci piring, menyirami tanaman. Lalu, sebagai bukti bahwa siswa telah mengerjakan hal tersebut, orang tua/wali murid diam-diam mengambil gambar/memfoto anak saat menjalankan tugasnya kemudian foto tersebut dikirim kepada guru melalui aplikasi Whatsapp. [8]

Pada titik ini, tekanan tentu menjadi terasa lebih berat, sehingga peserta didik melakukan banyak down mental dimana salah satunya adalah terlibat dengan penggunaan media social yang belebihan, membuat mental anak menjadi down selain itu penggunaan gadget juga merusak mata anak sedikit demi sedikit.[9] Jadi pada titik ini, seharusnya media social menjadi salah satu jalan keluar meretas rasa bosan,down mental ataupun stress karena belajar di rumah. Hanya saja, keaadan menjadi berbeda selama pandemic Covid. Disamping keharusan belajar dalam jaringan yang menjadi kendala lainnya adalah kurangnya fasilitas penunjang pembelajaran online seperti yang dialami oleh beberapa murid di SD Muhammadiyah 5 Porong memang dapat dikatakan sebagai sebuah kendala dalam proses berlangsungnya pembelajaran, namun usaha tetap harus dilakukan semaksimal mungkin, mengingat, sebagai orang tua wajib memberikan yang terbaik untuk anakanaknya termasuk harta berupa pendidikan. Melalui pemanfaatan inovasi pembelajaran berbasis IT, guru dapat meningkatkan minat dan motivasi belajar siswa. Namun dalam penerapan media pembelajaran berbasis IT, guru juga harus mempertimbangkan beberapa kendala yang akan dihadapi.

\section{Kesimpulan}

Pembelajaran online juga diterapkan di SD Muhammadiyah 5 Porong pada masa pandemi covid-19 ini, pembelajaran dilakukan secara jarak jauh yang sudah dilaksanakan dari pertengahan bulan maret 2019 lalu. Pembelajaran online ini dilaksanakan sesuai kebijakan yang telah ditentukan oleh pemerintah untuk memutus mata rantai penyebaran virus covid-19 ini. Adapun hasil wawancara yang dilakukan yaitu Guru sangat keberatan dengan adanya pembelajaran online ini khususnya pada pembelajaran pada Kelas Rendah, mungkin untuk kelas tinggi tidak terlalu berat tetapi untuk kelas rendah pembelajaran online ini sanngat berpengaruh terhadap perkembangan belajar anak. Namun ada sisi positif nya menggunakan smartphone siswa SD dapat mengerjakan tugas sekolah dari guru dengan mudah, dengan cepat dan banyak dan terjadwal, karena hakekat tugas diberikan sebagai bagian dari proses pembelajaran, maka tugas belajar dikerjakan siswa sesuai dengan pokok bahasan materi pelajaran.

\section{Ucapan Terima Kasih}

Tak lupa saya sampaikan terima kasih kepada Bapak dan ibu guru SD Muhammadiyah 5 Porong yang telah memberikan informasi tentang Pengaruh Pembelajaran Online Terhadap Perkembangan Siswa SD Muhammadiyah 5 Porong di Tengah Pandemi Covid 19. 


\section{References}

[1] Jannah, M., Nurdiyanti, N. "Jurnal Riset dan Inovasi Pembelajaran." Pengaruh Pembelajaran Online Berbantuan Google Classroom Terhadap Hasil Belajar Siswa Sma Pada Materi Sistem Peredaraan Darah Pada Manusia, 2021, pp. 75-84.

[2] Mohammad Salehudin, Marniah, Hariati. "Siswa Sd Menggunakan Smartphone Dalam Pembelajaran Online.” 2020, pp. 229-241

[3] Briliannur Dwi C, Aisyah Amelia, Uswatun Hasanah, Abdy Mahesha Putra, Hidayatur Rahman. "Analisis Keefektifan Pembelajaran Online di Masa Pandemi Covid-19." Jurnal Pendidikan Guru Sekolah Dasar, pp. 28-37

[4] Sugiyono, S., "Metode penelitian kuantitatif dan kualitatif dan R\&D," 2010

[5] Fatoni Achmad,1 Risna Srinawati,2 Alivia Septa Pamungkas,3. "Pengaruh Situs Pembelajaran Online Terhadap Proses Pembelajaran Siswa Di Madrasah Aliyah AlBairuny Jombang.” Jurnal Sosial dan Keagamaan, vol. Volume 09, 2020, pp. 264-288

[6] Hendri Yazid1 , Neviyarni2. "Pengaruh Pembelajaran Daring Terhadap Psikologis Siswa Akibat Covid-19.” Jurnal Human Care, vol. Volume 6, 2021, pp. 207-213

[7] Oktafia Ika Handarini, Siti Sri Wulandari. "Pembelajaran Daring Sebagai Upaya Study From Home (SFH) Selama Pandemi Covid 19." Jurnal Pendidikan Administrasi Perkantoran, vol. Volume 8, 2020, pp. 496-503, https://journal.unesa.ac.id/index.php/jpap

[8] Unik Hanifah Salsabila1, Siti Nurfajri Utami2 , Ashadatul Zahra3 , Fikri Haikal4, Acep Cahyono5. "Pengaruh Penggunaan Media Belajar Online Selama Pandemi." Jurnal Ilmiah Wahana Pendidikan, vol. Vol. 7, 2021, pp. 1-9.

[9] Laily Yuniar Nur'Azizah1 , Balqis Marta Lestari2 , Ina Magdalena3 ,. "Dampak Mental Bagi Siswa Sdn Buaran Mangga Ii Akibat Pembelajaran Jarak Jauh.” Jurnal Ilmiah Indonesia,, 2021, pp. 121-129 